\title{
Above- ANd Belowground CARbon Allocation IN Post-Fire LodgePole Pine Forests: EfFects of Tree Density AND STAND Age
}

\author{
CREIGHTON M. LITTON $\downarrow$ DENNIS H. KNIGHT \\ DEPARTMENT OF BOTANY $\downarrow$ UNIVERSITY OF WYOMING $\downarrow$ LARAMIE \\ MiCHAEL G. RYAN \\ US FOREST SERVICE $\downarrow$ ROCKY MOUNTAIN RESEARCH STATION
}

\begin{abstract}
$\downarrow$ ABSTRACT
Validating the different components of the carbon (C) budget in forest ecosystems is essential for developing allocation rules that allow accurate predictions of global $\mathrm{C}$ pools and fluxes. In addition, a better understanding of the effects of natural disturbances on $\mathrm{C}$ cycling is critical - particularly in light of changes in disturbance regimes that may occur with alterations in global climate. This study investigates the indirect effects of fire on $\mathrm{C}$ cycling in lodgepole pine (Pinus contorta var. latifolia Engelm. ex Wats.) stands in Yellowstone National Park by examining above- and belowground $\mathrm{C}$ pools, fluxes and allocation patterns in post-fire stands that vary in tree density and stand age (four forest types: low ( $<1000$ trees/ha), moderate $(7,000-40,000$ trees/ha), and high tree densities $(>50,000$ trees/ha) in 13-yrold stands; and $~ 110$-yr-old mature stands). Aboveand belowground biomass were estimated to investigate the effect of tree density on biomass partitioning in young stands. The effect of tree density on soil-surface $\mathrm{CO}_{2}$ efflux $\left(F_{\mathrm{S}}\right)$ and microbial biomass $\mathrm{C}\left(C_{\text {mic }}\right)$ in young stands was also examined, and data from mature stands were used as a proxy of pre-fire conditions to estimate the extent of ecosystem recovery 13 years after a stand replacing fire. Finally, the effects of tree density and stand age on ecosystem $\mathrm{C}$ pools, fluxes and allocation patterns were investigated. Partitioning of biomass to belowground increased with tree density in young
\end{abstract}

stands primarily as a result of inherent differences associated with tree size, not competition. $F_{\mathrm{S}}$ and $C_{\text {mic }}$ increased with tree density in young stands and with stand age, and both $F_{\mathrm{S}}$ and $C_{\text {mic }}$ were correlated exclusively with biotic variables. These findings support recent studies demonstrating the prevailing importance of plants in controlling overall rates of $F_{\mathrm{S}}$, and suggest that increased decomposition of older, recalcitrant soil $\mathrm{C}$ pools is relatively unimportant following fire. Fire, through influences on tree density and stand age, has important and lasting effects on the magnitude of $\mathrm{C}$ pools and fluxes in lodgepole pine ecosystems. However, results presented here suggest that overall $\mathrm{C}$ allocation patterns following fire are independent of tree density and stand age.

\section{$\downarrow \quad$ INTRODUCTION}

Globally, forests are the most important carbon (C) pool in terrestrial ecosystems (Dixon et al. 1994), containing $66-80 \%$ of all $C$ stored in aboveground biomass and $\sim 45 \%$ of that found in belowground terrestrial pools (Dixon and Turner 1991, Smith et al. 1993, Waring and Running 1998). Moreover, forests account for as much as $75 \%$ of terrestrial net primary productivity (Melillo et al. 1993). Within forests, an average of $69 \%$ of ecosystem $\mathrm{C}$ is found belowground in living biomass and soil organic matter pools (Dixon et al. 1994), 
although this number can reach $75 \%$ or higher in some systems (Keith et al. 1997). While significant advances have been made recently in understanding terrestrial $\mathrm{C}$ cycling, there are still rather large uncertainties pertaining to important and fundamental processes. For example, of all the $\mathrm{C}$ fixed during photosynthesis, where does it go? What is the magnitude of belowground $\mathrm{C}$ allocation, and what environmental variables control it? What happens to $\mathrm{C}$ pools and fluxes over the lifetime of a forest? What effect do natural and anthropogenic disturbances have on $\mathrm{C}$ pools and fluxes in forests? Do patterns, or "rules", of C allocation exist and, if so, what are they?

Our ability to assess how global change will affect $\mathrm{C}$ cycling in forest ecosystems lies, in large part, with the predictive capabilities of models. However, modelling terrestrial ecosystem metabolism - and changes that may occur due to alterations in global climate - is currently limited by an incomplete understanding of $\mathrm{C}$ allocation patterns (Ryan et al. 1997, Friedlingstein et al. 1999, Gower et al. 1999). In particular, belowground $C$ allocation is one of the poorest understood attributes of terrestrial ecosystems and represents a major uncertainty in global estimates of terrestrial productivity (Lauenroth 2000, Geider et al. 2001). Yet, belowground net primary production (BNPP) often accounts for $>60 \%$ of total NPP in forests (Nadelhoffer and Raich 1992, Gower et al. 2001, Law et al. 2001), and the allocation of $\mathrm{C}$ belowground by plants is the single largest component of gross primary production (Davidson et al., in press).

Along with uncertainties pertaining to allocation patterns, most ecosystem models that are used to simulate terrestrial $\mathrm{C}$ cycling do not take into account the effects of natural disturbances, making the accuracy of modeled $\mathrm{C}$ budgets questionable (Gower et al. 2001, Chen et al. 2002). Yet disturbances are an important component of all terrestrial ecosystems. Natural disturbances, particularly fire, lead to patchy landscapes characterized by a mosaic of stands differing in age and structural characteristics (e.g., tree density) (Turner et al. 1994, Turner et al. 1997, Foster et al. 1998). This landscape mosaic, in turn, influences regional patterns of energy flow, nutrient cycling, and susceptibility to future disturbances (Turner and Dale 1998). The frequency, size, and intensity of disturbances are contingent upon weather and climate as well as forest structure and composition (Dale et al. 2001). Projected climate change is, therefore, expected to result in modifications to natural disturbance regimes (Overpeck et al. 1990, Baker
1995, Turner et al. 1998, He et al. 1999). Altered disturbance regimes, whether caused by management activities or climate, could potentially have large impacts on $\mathrm{C}$ cycling in forest ecosystems.

Quantifying the important components of the $\mathrm{C}$ cycle during ecosystem recovery from fire is fundamental for determining how fire will alter regional and global $\mathrm{C}$ budgets (Auclair and Carter 1993, Houghton 1996, Burke et al. 1997, Amiro 2001). Fire immediately changes C cycling, returning large amounts of $\mathrm{CO}_{2}$ to the atmosphere (Harden et al. 2000). In addition to the direct combustion of organic matter, however, fire also has indirect effects on $\mathrm{C}$ cycling in forest ecosystems. Following fire, changes in productivity, the quantity and quality of $\mathrm{C}$ pools, and environmental site conditions can directly influence the flux of $\mathrm{C}$ from forest ecosystems (Burke et al. 1997). Consequently, the amount of $\mathrm{C}$ released to the atmosphere via postfire $\mathrm{CO}_{2}$ emissions can be two to six times greater than during the initial combustion of biomass (Auclair and Carter 1993, Dixon and Krankina 1993).

Here I present the major findings of my dissertation research (Litton 2002) that was designed to examine the indirect effects of fire (i.e., tree density and stand age) on above- and belowground $\mathrm{C}$ pools, fluxes and allocation patterns in a lodgepole pine (Pinus contorta var. latifolia Engelm. ex Wats.) ecosystem. The term $\mathrm{C}$ allocation has been used in terrestrial ecosystem studies to mean everything from cumulative patterns in standing biomass, to the flux of $\mathrm{C}$ to a particular component per unit time, to the distribution of flux as a fraction of gross photosynthesis. In this work I use the terms biomass partitioning to describe the distribution of standing biomass (e.g., root : shoot ratios), pools to describe the standing stock of $\mathrm{C}$ in a particular ecosystem component (e.g., vegetation, detritus, etc. in $\mathrm{g} \mathrm{C} / \mathrm{m}^{2}$ ), flux to describe the flow of $\mathrm{C}$ to/from a particular component per unit area per unit time (e.g., aboveground net primary productivity or soil-surface $\mathrm{CO}_{2}$ efflux in $\mathrm{g} \mathrm{C} \mathrm{m}^{2} \mathrm{yr}^{-1}$ ), and $\mathbf{C}$ allocation to describe overall, stand levél patterns in current year's flux and the partitioning of gross primary productivity (GPP).

\section{METHODS}

I used a full factorial design with four replicates of four forest types (low $(<1,000$ trees/ha), moderate $(7,000-40,000$ trees/ha), and high $(>50,000$ trees/ha) densities in 13-yr-old stands; and mature stands $\sim 110$-yrs-old) to investigate the effects of tree 
density and stand age, as influenced by fire, on above- and belowground $\mathrm{C}$ pools, fluxes and allocation patterns. All stands were located within Yellowstone National Park, WY.

Allometric equations were developed for predicting coarse root biomass from basal diameter for 13-yr-old lodgepole pine trees. The regression equations for coarse root biomass were then used in conjunction with existing allometric equations for aboveground biomass and fine root biomass estimates from coring to estimate belowground, aboveground and total stand tree biomass in 12 young (13-yr-old) post-fire lodgepole pine stands covering a wide range of tree densities. The effect of fire on soil $\mathrm{C}$ pools and fluxes in post-fire lodgepole pine stands was also investigated. The 13-yr-old stands were used to examine the effect of tree density on soil-surface $\mathrm{CO}_{2}$ efflux $\left(F_{\mathrm{S}}\right)$ and microbial biomass $\mathrm{C}\left(C_{\text {mic }}\right)$ in young stands, and data from mature stands were used as a proxy of pre-fire conditions to estimate the rate and extent of ecosystem recovery 13 years after a stand-replacing fire. Finally, ecosystem C pools (above- and belowground plant biomass; soil organic matter; litter layer; coarse woody debris), fluxes (aboveground net primary productivity and total belowground carbon allocation), and allocation patterns were examined in my 16 stands to investigate how they vary with tree density and stand age. Above- and belowground biomass were estimated from allometric equations, and $\mathrm{C}$ pools in detritus, fine roots, and soils were sampled directly. Aboveground net primary productivity (ANPP) was estimated as aboveground biomass increment plus fine litterfall, and total belowground carbon allocation (TBCA) was estimated using a $\mathrm{C}$ balance approach.

\section{RESULTS \& DISCUSSION}

\section{Biomass partitioning}

Belowground biomass partitioning increased with tree density, but the increase was determined by inherent differences associated with tree size, not competition. Stand biomass in trees ranged from 46 $5,529 \mathrm{~kg} \cdot \mathrm{ha}^{-1}$ belowground, $176-9,400 \mathrm{~kg} \cdot \mathrm{ha}^{-1}$ aboveground, and $222-13,685 \mathrm{~kg} \cdot \mathrm{ha}^{-1}$ for total biomass. For individual trees, the ratio of belowground : total biomass declined with tree size from 0.44 at a basal diameter of $0.5 \mathrm{~cm}$ to 0.11 at a basal diameter of $8 \mathrm{~cm}$. This shift in individual tree biomass partitioning caused the proportion of total stand biomass in belowground tissues to increase from $19 \%$ in low density stands with larger trees to $31 \%$ in high density stands with small trees.

Given the paucity of data, belowground biomass is often estimated as a proportion of total stand biomass using variables such as root : shoot ratios. Mean values that span a great variety of tree species, stand densities, age classes, and site quality are used to make inferences about broad scale biomass patterns and carbon dynamics. The use of average values makes the reliability of such assessments questionable. The results from this and previous studies suggest that biomass partitioning in coniferous forests changes across gradients of stand age and tree density.

\section{Soil C pools and fluxes}

Growing season soil-surface $\mathrm{CO}_{2}$ efflux $\left(F_{\mathrm{S}}\right)$ increased with tree density in young stands $(1.0 \mu \mathrm{mol}$ $\mathrm{CO}_{2} \cdot \mathrm{m}^{-2} \cdot \mathrm{s}^{-1}$ in low density stands, $1.8 \mu \mathrm{mol} \mathrm{CO} \cdot \mathrm{m}^{-2} \cdot \mathrm{s}^{-1}$ in moderate density stands, and $2.1 \mu \mathrm{mol} \mathrm{CO} \mathrm{CO}_{2} \cdot \mathrm{m}^{-2} \cdot \mathrm{s}^{-1}$ in high density stands $)$ and with stand age $(2.7 \mu \mathrm{mol}$ $\mathrm{CO}_{2} \cdot \mathrm{m}^{-2} \cdot \mathrm{s}^{-1}$ in mature stands). Microbial biomass carbon $\left(C_{\text {mic }}\right)$ in young stands did not differ with tree density and ranged from $0.2-0.5 \mathrm{mg} \mathrm{C} \cdot \mathrm{g}^{-1}$ dry soil over the growing season; $C_{\text {mic }}$ was significantly greater in mature stands $\left(0.5-0.8 \mathrm{mg} \mathrm{C} \cdot \mathrm{g}^{-1}\right.$ dry soil).

Immediately following fire, $F_{\mathrm{S}}$ should be the exclusive product of microbial activity and decomposition of labile soil $\mathrm{C}$ pools. As labile pools become depleted and plant regrowth occurs, $F_{\mathrm{S}}$ will be the product of root respiration and microbial decomposition of new inputs of labile C (e.g., root exudates), as well as any decomposition of older, recalcitrant pools of soil C. If the decomposition of older pools with slow turnover rates increases with post-fire changes in the soil environment, then the potential exists for the loss of a relatively long-term terrestrial $\mathrm{C}$ pool following fire.

$F_{\mathrm{S}}$ in my young stands was correlated with biotic variables (aboveground, belowground, and microbial biomass), but not with abiotic variables (mineral soil $\mathrm{C}$ and $\mathrm{N}$ content, bulk density, and soil texture). $C_{\text {mic }}$ was correlated with belowground plant biomass, and not with mineral soil $\mathrm{C}$ and $\mathrm{N}$, suggesting that plant activity controls not only root respiration, but $C_{\text {mic }}$ pools and overall $F_{\mathrm{S}}$ rates as well. Taken together, these results suggest that labile $\mathrm{C}$ inputs in the rhizosphere are more important than bulk soil decomposition processes in controlling overall microbial activity and that plant activity controls $F_{\mathrm{S}}$ in forests recovering from stand-replacing fire. These findings agree with recent work that has 
shown that net primary productivity and the flux of $\mathrm{C}$ assimilates to roots are the main determinants of $F_{\mathrm{S}}$ (Fitter et al. 1998, Fitter et al. 1999, Ekblad \& Högberg 2001, Högberg et al. 2001, Janssens et al. 2001). The apparent lack of increased decomposition of older, recalcitrant pools in post-fire stands means that fire does not necessarily affect this relatively long-term pool of $\mathrm{C}$ in soils.

\section{C allocation patterns}

My results indicate that fire clearly affects the magnitude of $\mathrm{C}$ pools and fluxes through its influence on tree density and stand age. Coarse woody debris and mineral soil carbon accounted for the majority of total ecosystem $\mathrm{C}$ in young stands $(91-99 \%)$, in contrast to mature stands where the largest amount of $\mathrm{C}$ was found in live biomass (64\%). ANPP and TBCA increased with tree density $\left(P<0.01\right.$; mean ANPP was 59,122 , and $156 \mathrm{~g} \mathrm{C} \cdot \mathrm{m}^{-}$ ${ }^{2} \cdot \mathrm{yr}^{-1}$ and TBCA was 68,237 , and $306 \mathrm{~g} \mathrm{C} \cdot \mathrm{m}^{-2} \cdot \mathrm{yr}^{-1}$ for low, moderate and high density young stands, respectively), and with stand age $(P<0.01$; ANPP was 218 and TBCA was $382 \mathrm{~g} \mathrm{C} \cdot \mathrm{m}^{-2} \cdot \mathrm{yr}^{-1}$ for $110-\mathrm{yr}-$ old stands). ANPP and TBCA were positively correlated $(P<0.01)$, and both variables were well correlated with leaf area index $(P<0.01)$. Notably, the ratio of TBCA : TBCA + ANPP remained remarkably constant (0.63-0.66) across extreme gradients of tree density and stand age, differing only slightly for the low density young stands (0.54). These findings suggest that $\mathrm{C}$ allocation patterns following natural disturbance are independent of tree density and stand age, despite increased competition for limiting resources.

The approach outlined here could be used to enhance the scope and accuracy of terrestrial C models by identifying allocation patterns that allow for estimation of belowground $\mathrm{C}$ dynamics from commonly measured aboveground variables (e.g., ANPP or LAI). In addition, increased understanding of the effects of natural disturbance on the net exchange of $\mathrm{C}$ in forests via changes in stand structure and age will enable more accurate $\mathrm{C}$ modelling and better predictions of the effects of global change biology on terrestrial $\mathrm{C}$ cycling. The ability to incorporate the effects of natural disturbance in modelling efforts is particularly important in light of predictions that disturbances, particularly fire, will increase in frequency and intensity with projected changes in climate.

\section{$\downarrow \quad$ CONCLUSIONS}

The research presented here provides information on the indirect effects of fire, as a natural disturbance, on $\mathrm{C}$ cycling in a lodgepole pine ecosystem. However, future research is needed to provide additional information that will help constrain estimates of terrestrial $\mathrm{C}$ cycling following fire. Coarse woody debris (CWD) was an important component of total ecosystem $\mathrm{C}$ in young post-fire lodgepole pine stands, yet little information exists regarding the flux of $\mathrm{C}$ from $\mathrm{CWD}$ to the atmosphere via decomposition. Total ecosystem respiration (TER) accounts for as much as $80 \%$ of GPP in forest ecosystems (Janssens et al. 2001), and soil respiration has been shown to be the largest component of TER in forests (Law et al. 1999, Janssens et al. 2001, Xu et al. 2001). But what role does CWD play in ecosystem respiration in post-fire stands? CWD dynamics may well constrain net ecosystem exchange (NEE, the net $\mathrm{CO}_{2}$ exchange between ecosystems and the atmosphere) in post-fire forests over long time periods.

In addition to $\mathrm{CWD}, \mathrm{C}$ in the form of charcoal in soils may play an important role in controlling NEE. During an intense crown fire in a mature lodgepole pine forest, approximately $8 \%$ of plant biomass is converted to charcoal. It is likely that most, or all, of that charcoal is eventually incorporated into the soil where it resides for an unknown time in the recalcitrant pool of soil organic matter. What role does charcoal formation during wildfire play in long-term storage of $\mathrm{C}$ in forest ecosystems? Finally, my stand age comparison includes data from stands that represent only two points in time (i.e., young vs. mature). What happens to $\mathrm{C}$ pools and fluxes over the entire course of stand development? It is possible that important differences in $\mathrm{C}$ cycling occur during the first several years following a fire or in subsequent years as stands develop. Realistic modelling of terrestrial $\mathrm{C}$ cycling should take into account $\mathrm{C}$ pools and fluxes for stands of all ages.

\section{ACKNOWLEDGEMENTS}

This research was supported by the generosity and good will of many people and various funding agencies, including the Ecology and Ecosystems Program of the National Science Foundation (Grant No. DEB-9806440); the University of Wyoming-National Park Service Research Station small grants program; the Mellon 
Foundation; the USDA Forest Service, Rocky Mountain Research Station; and a Wyoming NASA Space Grant Graduate Research Fellowship (NASA Grant \#NGT-40102).

\section{$\downarrow$ Literature Cited}

Amiro, B. D. 2001. Paired-tower measurements of carbon and energy fluxes following disturbance in the boreal forest. Global Change Biology 7:253-268.

Auclair, A. N. D., and T. B. Carter. 1993. Forest wildfires as a recent source of $\mathrm{CO}_{2}$ at northern latitudes. Canadian Journal of Forest Research 23:1528-1536.

Baker, W. L. 1995. Long-term response of disturbance landscapes to human intervention and global change. Landscape Ecology 10:143-159.

Burke, R. A., R. G. Zepp, M. A. Tarr, W. L. Miller, and B. J. Stocks. 1997. Effect of fire on soilatmosphere exchange of methane and carbon dioxide in Canadian boreal forest sites. Journal of Geophysical ResearchAtmospheres 102:29289-29300.

Chen, W., J. M. Chen, D. T. Price, and J. Cihlar. 2002. Effects of stand age on net primary productivity of boreal black spruce forests in Ontario, Canada. Canadian Journal of Forest Research 32:833-842.

Dale, V. H., L. A. Joyce, S. McNulty, R. P. Neilson, M. P. Ayres, M. D. Flannigan, P. J. Hanson, L. C. Irland, A. E. Lugo, C. J. Peterson, D. Simberloff, F. J. Swanson, B. J. Stocks, and B. M. Wotton. 2001. Climate change and forest disturbances. BioScience 51:723-734.

Davidson, E. A., K. Savage, P. Bolstad, D. A. Clark, P. S. Curtis, D. S. Ellsworth, P. J. Hanson, B. E. Law, Y. Luo, K. S. Pregitzer, J. C. Randolph, and D. Zak. In press. Belowground carbon allocation in forests estimated from litterfall and IRGA-based soil respiration measurements. Ecology.

Dixon, R. K., S. Brown, R. A. Houghton, A. M. Solomon, M. C. Trexler, and J. Wisniewski. 1994. Carbon pools and flux of global forest ecosystems. Science 263:185-190.
Dixon, R. K., and O. N. Krankina. 1993. Forest fires in Russia: carbon dioxide emissions to the atmosphere. Canadian Journal of Forest Research 23:700-705.

Dixon, R. K., and D. P. Turner. 1991. The global carbon cycle and climate change - responses and feedbacks from belowground systems. Environmental Pollution 73:245-262.

Ekblad, A., and P. Högberg. 2001. Natural abundance of ${ }^{13} \mathrm{C}$ in $\mathrm{CO}_{2}$ respired from forest soils reveals speed of link between tree photosynthesis and root respiration. Oecologia 127:305-308.

Fitter, A. H., J. D. Graves, G. K. Self, T. K. Brown, D. S. Bogie, and K. Taylor. 1998. Root production, turnover and respiration under two grassland types along an altitudinal gradient: influence of temperature and solar radiation. Oecologia 114:20-30.

Fitter, A. H., G. K. Self, T. K. Brown, D. S. Bogie, J. D. Graves, D. Benham, and P. Ineson. 1999. Root production and turnover in an upland grassland subjected to artificial soil warming respond to radiation flux and nutrients, not temperature. Oecologia 120:575-581.

Foster, D. R., D. H. Knight, and J. F. Franklin. 1998. Landscape patterns and legacies resulting from large, infrequent forest disturbances. Ecosystems 1:497-510.

Friedlingstein, P., G. Joel, C. B. Field, and I. Y. Fung. 1999. Toward an allocation scheme for global terrestrial carbon models. Global Change Biology 5:755-770.

Geider, R. J., E. H. Delucia, P. G. Falkowski, A. C. Finzi, J. P. Grime, J. Grace, T. M. Kana, J. La Roche, S. P. Long, B. A. Osborne, T. Platt, I. C. Prentice, J. A. Raven, W. H. Schlesinger, V. Smetacek, V. Stuart, S. Sathyendranath, R. B. Thomas, T. C. Vogelmann, P. Williams, and F. I. Woodward. 2001. Primary productivity of planet earth: biological determinants and physical constraints in terrestrial and aquatic habitats. Global Change Biology 7:849-882. 
Gower, S. T., O. Krankina, R. J. Olson, M. Apps, S. Linder, and C. Wang. 2001. Net primary production and carbon allocation patterns of boreal forest ecosystems. Ecological Applications 11:1395-1411.

Gower, S. T., C. J. Kucharik, and J. M. Norman. 1999. Direct and indirect estimation of leaf area index, $\mathrm{f}_{\mathrm{APAR}}$, and net primary production of terrestrial ecosystems. Remote Sensing of Environment 70:29-51.

Harden, J. W., S. E. Trumbore, B. J. Stocks, A. Hirsch, S. T. Gower, K. P. O'Neill, and E. S. Kasischke. 2000. The role of fire in the boreal carbon budget. Global Change Biology 6:174-184.

He, H. S., D. J. Mladenoff, and T. R. Crow. 1999. Linking an ecosystem model and a landscape model to study forest species response to climate warming. Ecological Modelling 114:213-233.

Högberg, P., A. Nordgren, N. Buchmann, A. F. S. Taylor, A. Ekblad, M. N. Högberg, G. Nyberg, M. Ottosson-Lofvenius, and D. J. Read. 2001. Large-scale forest girdling shows that current photosynthesis drives soil respiration. Nature 411:789-792.

Houghton, R. A. 1996. Terrestrial sources and sinks of carbon inferred from terrestrial data. Tellus 48B:420-432.

Janssens, I. A., H. Lankreijer, G. Matteucci, A. S. Kowalski, N. Buchmann, D. Epron, K. Pilegaard, W. Kutsch, B. Longdoz, T. Grunwald, L. Montagnani, S. Dore, C. Rebmann, E. J. Moors, A. Grelle, U. Rannik, K. Morgenstern, S. Oltchev, R. Clement, J. Gudmundsson, S. Minerbi, P. Berbigier, A. Ibrom, J. Moncrieff, M. Aubinet, C. Bernhofer, N. O. Jensen, T. Vesala, A. Granier, E. D. Schulze, A. Lindroth, A. J. Dolman, P. G. Jarvis, R. Ceulemans, and R. Valentini. 2001. Productivity overshadows temperature in determining soil and ecosystem respiration across European forests. Global Change Biology 7:269-278.

Keith, H., R. J. Raison, and K. L. Jacobsen. 1997. Allocation of carbon in a mature eucalypt forest and some effects of soil phosphorus availability. Plant and Soil 196:81-99.
Lauenroth, W. K. 2000. Methods of estimating belowground net primary production. Pages 58-71 in O. E. Sala, R. B. Jackson, H. A. Mooney, and R. W. Howarth, editors. Methods in Ecosystem Science. Springer, New York.

Law, B. E., M. G. R yan, and P. M. A nthoni. 1999 Seasonal and annual respiration of a ponderosa pine ecosystem. Global Change Biology 5:169-182.

Law, B. E., P. E. Thornton, J. Irvine, P. M. Anthoni, and S. Van Tuyl. 2001. Carbon storage and fluxes in ponderosa pine forests at different developmental stages. Global Change Biology 7:755-777.

Litton, C. M. 2002. Above- and belowground carbon allocation in post-fire lodgepole pine forests: effects of tree density and stand age. Ph.D. Dissertation, Department of Botany, University of Wyoming, Laramie, WY, USA.

Melillo, J. M., A. D. McGuire, D. W. Kicklighter, B. Moore, C. J. Vorosmarty, and A. L. Schloss. 1993. Global climate change and terrestrial net primary production. Nature 363:234-240.

Nadelhoffer, K. J., and J. W. Raich. 1992. Fine root production estimates and belowground carbon allocation in forest ecosystems. Ecology 73:1139-1147.

Overpeck, J. T., D. Rind, and R. Goldberg. 1990. Climate-induced changes in forest disturbance and vegetation. Nature 343:5153.

Ryan, M. G., M. B. Lavigne, and S. T. Gower. 1997. Annual carbon cost of autotrophic respiration in boreal forest ecosystems in relation to species and climate. Journal of Geophysical Research 102:28871-28884.

Smith, T. M., W. P. Cramer, R. K. Dixon, R. Leemans, R. P. Neilson, and A. M. Solomon. 1993. The global terrestrial carbon cycle. Water Air and Soil Pollution 70:1937.

Turner, M. G., W. L. Baker, C. J. Peterson, and R. K. Peet. 1998. Factors influencing succession: Lessons from large, infrequent natural disturbances. Ecosystems 1:511-523. 
Turner, M. G., and V. H. Dale. 1998. Comparing large, infrequent disturbances: What have we learned? Ecosystems 1:493-496.

Turner, M. G., W. W. Hargrove, R. H. Gardner, and W. H. Romme. 1994. Effects of fire on landscape heterogeneity in Yellowstone National Park, Wyoming. Journal of Vegetation Science 5:731-742.

Turner, M. G., W. H. Romme, R. H. Gardner, and W. W. Hargrove. 1997. Effects of fire size and pattern on early succession in Yellowstone National Park. Ecological Monographs 67:411-433.
Waring, R. H., and S. W. Running. 1998. Forest Ecosystems: Analysis at Multiple Scales, 2nd edition. Academic Press, San Diego.

Xu, M., T. A. DeBiase, Y. Qi, A. Goldstein, and Z. G. Liu. 2001. Ecosystem respiration in a young ponderosa pine plantation in the Sierra Nevada Mountains, California. Tree Physiology 21:309-318. 